Debreceni Egyetem Fogorvostudományi Kar, Bioanyagtani és Fogpótlástani Tanszék*

Atommagkutató Intézet, Anyagtudományi Laboratórium, Debrecen**

Atommagkutató Intézet, Izotópklimatológai Laboratórium (IKER), Debrecen**

\title{
Zeolit és magnéziummal ioncserélt zeolit in vitro összehasonlító vizsgálata
}

\author{
SZILÁGYI ILDIKÓ*, DR. CZIBULYA ZSUZSANNA*, DR. CSÍK ATTILA** \\ DR. BRAUN MIHÁLY***, DR. HEGEDÜS CSABA*
}

\begin{abstract}
A zeolit és magnéziummal ioncserélt zeolitrendszer vizsgálata humán őssejteken és a különböző koncentrációk hatására bekövetkező eltérő életképesség és ALP aktivitás értékek információt nyújtanak a csontosodást, csont „turnovert” befolyásoló tényezőkről. Jelen munkánk célja a zeolit és a magnéziummal ioncserélt zeolit koncentrációk $(0,605 \mathrm{mM}$, $0,325 \mathrm{mM}, 0,15 \mathrm{mM}$ Mg-zeolit és zeolit) hatásának vizsgálata volt in vitro kísérleti rendszerben, tenyésztő médiumban bölcsességfog eredetű (DPSC) sejteken, különböző mintavételi időpontokban (1., 4., 7. és 14. nap).

Az életképesség és alkalikus foszfatáz aktivitás méréseink alapján mindkét vizsgált komponens, így a zeolit és a magnéziummal ioncserélt zeolit több területen is ígéretes összetevője lehet a jövő mesterséges szövettenyésztést alkalmazó orvosi beavatkozásainak. Kísérleteink alapján a Mg-zeolit bizonyult hatékonyabbnak a hagyományosan használt zeolittal szemben.
\end{abstract}

Kulcsszavak: magnézium, zeolit, DPSC, scaffold

\section{Bevezetés}

A szövettervezés az orvostudomány különböző területein nagy érdeklődésre tart számot. A csontpótlás, pl. traumák utáni regenerációs mútétek, kongenitális rendellenességek vagy pl. a fogorvostudományban a különböző parodontális megbetegedések, egyes fogászati implantológiai kezelések esetében a terápia fontos részét képezhetik. Az interdiszciplináris területek együttmúködésével a biotechnológia új területeket teremtett meg az elmúlt évtizedekben. Ezen területek kollaborációjának célja, hogy a sérült, károsodott szövetek regenerálásához a megfelelő feltételek adottak legyenek. A legfontosabb komponensek ehhez: a scaffoldok, a sejtek és a szignalizációs molekulák. A jól felhasználható scaffold követelményei a 3D szerkezet megfelelő mechanikai tulajdonságai, mely a sejtek adhéziójához, proliferációjához, és differenciálódásához alapot szolgáltatnak. Szintén nagyon fontos a porózus szerkezet, így a szövetképződést elősegítő faktorok megfelelően érvényesülni tudnak. A biodegradábilis és kontrollált méret, a megfelelő alak elengedhetetlen a jól integrálódó scaffold tulajdonságaihoz. Ilyen lehetséges vázalkotók lehetnek a zeolitok [1, 6, 7, 8]. A porózus szilikátok iránt jelentős tudományos és technológiai érdeklődés mutatkozik, mivel nagy fajlagos felületű anyagok, tehát adszorpciós és katalitikus célokra egyaránt alkalmasak. A zeolitok kristályos, térhálós aluminoszilikátok, melyek- ben a $\mathrm{SiO}_{4}$ és az $\mathrm{AlO}_{4}$ tetraéderek összekapcsolódásával alakul ki a mezopórusos kapilláris rendszer. A zeolitok kémiai összetétele és ezzel együtt a tulajdonságai az adott felhasználási célnak megfelelően módosíthatók a rácsszerkezet megváltozása nélkül. Alacsony költségük, alacsony toxicitásuk, nagy felületük, változtatható porozitásuk és a sejtek számára gyors diffúziót biztosító kapilláris rendszerük, valamint nagymértékú mechanikai szilárdságuk előnyt jelent a mesterséges szövetek előállításakor [12, 14]. A zeolitok ezen pozitív tulajdonságai, valamint a sokféleképpen alakítható felszíni csoportok befolyásolják és kontrollálhatóvá teszik a hidrofil/hidrofób jellemzőiket is. Az antibakteriális, antitumor, antitrombotikus, homeosztázist befolyásoló tulajdonságaik is lehetővé teszik az emberi szervezetben történő alkalmazásukat. Molekula-karrier és a csontregenerációt elősegítő jellemzői szintén új lehetőségeket rejtenek magukban, különösen a fogászat területén. Zeolit MFI-vel (hidroxyapatit/zeolit coating) felületkezelt titánium implantátumok biokompatibilitása eredményesebb és elősegíti az osszeokondukciót, osszeoindukciót és osszeointegrációt. A zeolit 3D szerkezete elősegítette a sejtek korábbi megtapadását és növekedését majd az ECM (extracelluláris mátrix) szekréciójával a szövetképződést $[1,13]$. A zeolit mellett egy másik ígéretes anyag lehet a magnézium. A magnézium szerepe az emberi szervezetben nagyon sokrétű: kötődik ligand fehérjékhez, és sejtfelszíni receptorokhoz 
- pl. integrin szupercsaládhoz, vitronektin, fibronektin fibrinogénekez -, rengeteg enzim katalitikus centrumának központi ionja, részt vesz az RNS és DNS stabilizálásában. A magnézium a csontok „egészségi állapotában" is kulcsfontosságú szerepet tölt be. Nagyszámú irodalmi adat támasztja alá a magnézium oszteogenezisben és a csontok „remodelling” mechanizmusában betöltött funkcióját, de az élő szervezetekre ható különböző magnéziumion-koncentrációk hatása még ma sem ismert minden részletében [15, 18, 19, 20, 22, 24]. $\mathrm{Az}$ in vivo és in vitro kísérleti rendszerekben vizsgált biodegradábilis felületek segíthetik a jelenleginél gyorsabb osszeointegrációs folyamatokat és így az új fogászati és ortopédiai implantátumok fejlesztését. Az extracelluláris magnézium koncentráció vizsgálata információt adhat arról, hogy a sejtek milyen miliőben élhetnek optimális feltételek mellett. A különböző koncentrációkban jelen lévő ionok hatására bekövetkező eltérő differenciálódási, génexpressziós életképesség-karakterisztika mélyebb összefüggést, magyarázatot adhat a lokális és szisztémás magnéziumion-koncentrációk csontosodást, csont „turnovert” befolyásoló hatásáról.

Jelen munkánk célja a zeolit és a magnéziummal ioncserélt zeolit hatásának vizsgálta in vitro kísérleti rendszerben a magnéziumkoncentráció függvényében tenyésztő médiumban bölcsességfog eredetű (DPSC) sejteken, különböző mintavételi időpontokban.

\section{Anyagok és módszerek}

Mg-zeolit készítése: A zeolit minta ioncseréje $0,1 \mathrm{moldm}^{-3}$ koncentrációjú $\mathrm{MgCl}_{2}$ oldatból való $\mathrm{Mg}$-ion megkötéssel ment végbe. A zeolit mintát 24 órán keresztül, folyamatosan keverve áztattuk az oldatban.

Morfológiai és összetétel-meghatározó vizsgálatok, SEM és MP-AES vizsgálat alkalmazásával: Az eredeti és a módosított szemcséket morfológiai vizsgálatoknak vetettük alá. A felületi morfológiát téremissziós elektronforrással rendelkező JEOL JSM-IT500HR (Japán) típusú pásztázó elektronmikroszkópot (SEM) használva vizsgáltuk, az elektronbombázás okozta felületi tértöltés elkerülésére a mintákat $20 \mathrm{~nm}$-es aranyréteggel vontuk be. Az elemösszetétel meghatározás JEOL (EX-74232UiL4Q, Japán) energia-diszperzív röntgen detektorral történt. $\mathrm{Az}$ ioncserélt zeolit pontos Mg-ion tartalmát savas feltárás után mikrohullámú plazma atomemissziós spektrométerrel (MP-AES 4200, Agilent, USA) határoztuk meg.

Sejttenyésztés: A DPSC sejteket bölcsességfogakból izoláltuk a Debreceni Egyetem FOK intézményében (engedélyszám: ETT TUKEB 49849-3/2016/EKU). A fogat a fissura mentén elvágtuk, majd a pulpát a pulpakamrából eltávolítottuk steril körülmények között. A pulpa szövetet kollagenáz/diszpáz ( $3 \mathrm{mg} / \mathrm{ml}$, Sigma Aldrich USA, $4 \mathrm{mg} / \mathrm{ml}$, Gibco, USA) emésztő oldatban 1 órát $37^{\circ} \mathrm{C}$-on emésztettük. A sejtszuszpenziót (CTRL, kontrollsejtek) 6 lyukú plate-en tenyésztettük DMEM F12 (Gibco USA) médiumban, 10\% (v/v) FBS (Gibco USA),
$1 \%$ Glutamax (Gibco) és 1\% Antibiotic-Antimycotic (Gibco) jelenlétében és $37^{\circ} \mathrm{C}$-on $5 \% \mathrm{CO}_{2}$-tartalom mellett. A sejteket ugyanebben a médiumban tartottuk fenn (CM).

Alamar Blue: sejtéletképesség esszé (Invitrogen, Thermo Fisher USA). A sejtek életképességét az 1, 4, 7 és 14 napokon mértük. Az Alamar Blue oldatot tízszeres hígításban tettük a sejtek tenyésztőoldatához, majd $37^{\circ} \mathrm{C}$-on 1 órán át inkubáltuk. Ezt követően $200 \mu \mathrm{l}-\mathrm{t}$ a mintából 96 lyukú plate-en HIDEX Plate Reader segítségével $530 \mathrm{~nm}$ gerjesztési és $580 \mathrm{~nm}$ emissziós hullámhossz mellett detektáltunk.

ALP aktivitást: mérő esszé (Sigma Fast, Sigma Aldrich USA): A mineralizációs folyamatok vizsgálata során alkalikus foszfatáz aktivitását mérő kísérletet végeztünk 4, 7 és 14 napos DPSC sejttenyészeten, a tenyésztést követően. A sejteket 96 lyukú platen tenyésztettük 5000 sejt/well három parallel mintával. A mintavételi időpontokon PBS mosás után a sejteket begyüjtöttük és ALP lízis pufferben lizáltuk $(10 \mathrm{mM}$ Tris- $\mathrm{HCl}, 100 \mathrm{mM} \mathrm{NaCl}, 1 \mathrm{mM}$ Triton-X 100, 1\% PMSF and $1 \%$ protease inhibitor cocktail, $\mathrm{pH} 7,4)$. A kezelt és kontroll mintákat $-70^{\circ} \mathrm{C}$-on tároltuk ALP + PIC pufferben a felhasználásig. A sejtlizátumot 10 percig $16000 \mathrm{rpm}$ centrifugáltuk, majd a felülúszóból 30 l-t egy 96-os plateen $100 \mu l$ pNitrophenyl Phosphate Liquid Substrate System oldatot adtunk a gyártó utasításait követve (SigmaAldrich USA), majd HIDEX microplate readeren mértük az ALP aktivitást (Hidex, Finland). A 405 nm-en mért abszorbancia növekedése arányos a szérum alkalikus foszfatáz aktivitásával. A totál protein koncentrációt BCA Protein Assay Kit-tel (Thermo Scientific USA) határoztuk meg, és az ALP aktivitás értékeit ezzel normalizáltuk.

\section{Eredmények}

A zeolit és a magnéziummal ioncserélt zeolit minták morfológiáját bemutató pásztázó elektronmikroszkópos képek az 1. ábrán láthatóak. A képek 6000-szeres nagyítással készültek, a méretskála a képek jobb alsó sarkában látható. Megállapítottuk, hogy őrlés hatására mindkét minta szemcseeloszlása hasonló mérettartományban, 0,1-0,9 $\mu \mathrm{m}$ között mozog.

$\mathrm{Az}$ ioncserélt zeolit pontos $\mathrm{Mg}$-ion tartalmát savas feltárás után mikrohullámú plazma atomemissziós spektrométerrel határoztuk meg, a mérések alapján a $\mathrm{MgCl}_{2}$ oldatban végzett ioncsere sikeresnek bizonyult. A $\mathrm{Mg}^{2}$ iontartalom atomemissziós spektrométerrel $5,76 \mathrm{~g} / \mathrm{kg}$ nak; elemanalízissel (energia-diszperzív röntgen detektorával) mérve $5,58 \mathrm{~g} / \mathrm{kg}$ volt. A 2. ábrán látható a zeolit és a módosított zeolit atomi összetétele ioncsere előtt és után.

Sejtproliferáció- és életképesség-vizsgálatokkal következtethetünk a kísérletben vizsgált anyagok esetleges inkompatibilitására vagy toxicitására. A DPSC sejtek proliferációs indexét (abszorbanciáját) 0,605, 0,325 és $0,15 \mathrm{mM}$ Mg-zeolit és zeolit jelenlétében, valamint 

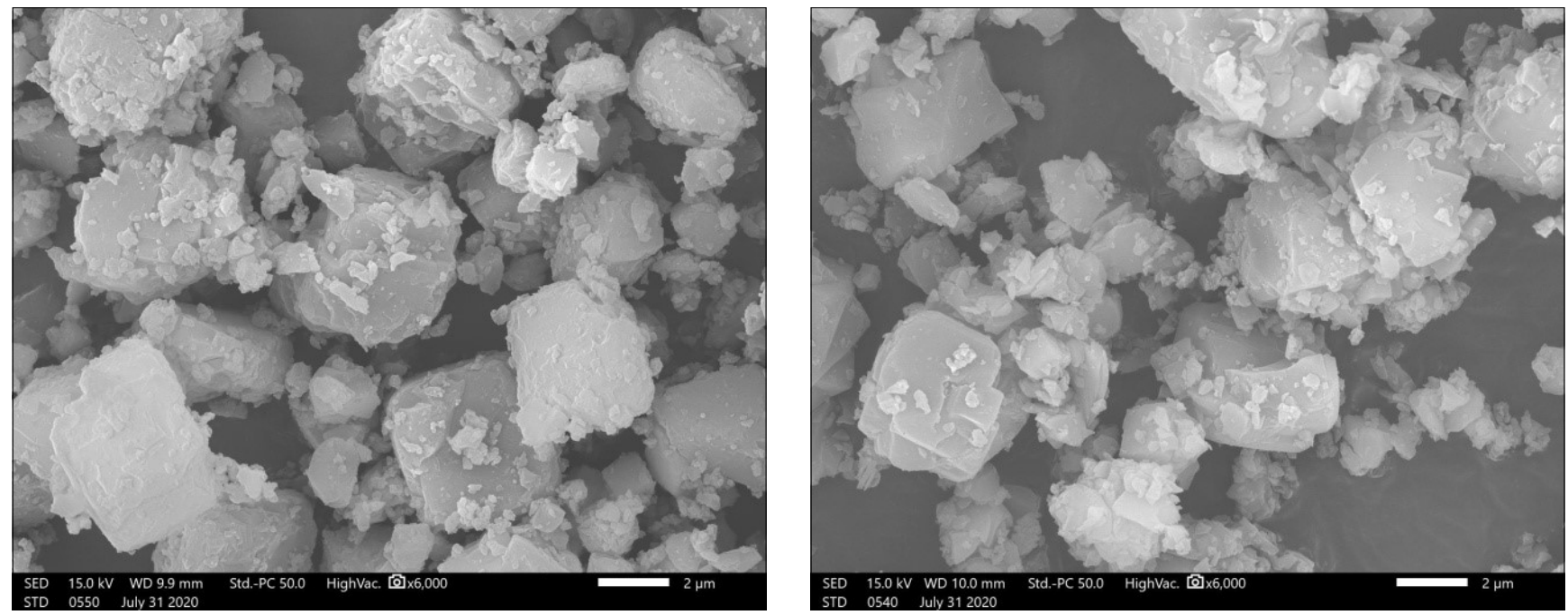

1. kép: Az őrölt zeolit (A) és őrölt Mg-zeolitl (B) pásztázó elektronmikroszkópos felvételei.

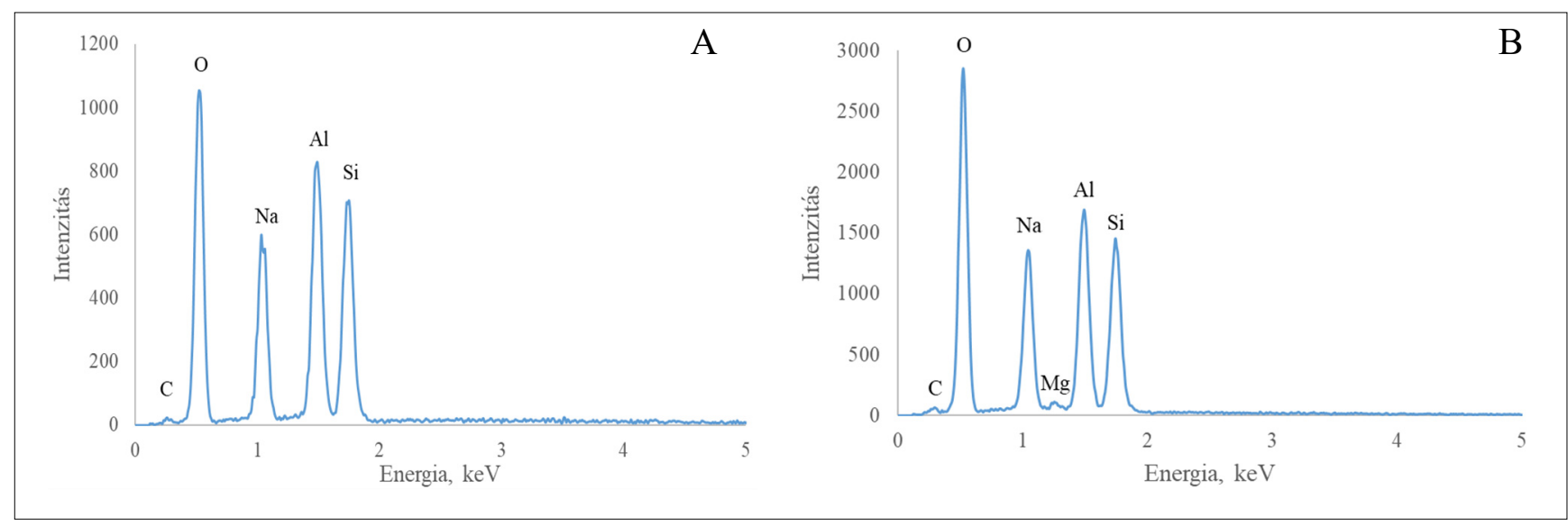

2. kép: A zeolit (A) és ioncserélt zeolit (B) elemanalízis méréseinek eredményei. Jól látható a magnézium megjelenése az ioncsere folyamat után.

a kontroll sejteken a 14. napon AlamarBlue esszével határoztuk meg (3. kép).

Az abszorbancia értékek alapján általános tendencia, hogy a tenyésztő médiumban mért értékek a Mg-zeolités zeolitkezelések az alacsonyabb koncentrációk esetében $(0,325,0,15 \mathrm{mM})$ mutattak magasabb értéket, az összes kezelés esetében a 14. napon a legmagasabbat. Magasabb zeolit- és Mg-zeolit-koncentrációk esetében az életképesség csökken. A Mg-zeolittal kezelt DPSC sejtek abszorbancia értékei a zeolit mintákkal összehasonlítva magasabbnak bizonyultak.

Az ALP-aktivitást mérő esszé (Sigma Fast) a mineralizációs folyamatok során kialakuló alkalikus foszfatáz aktivitását mutatja ki. Kísérletünk során a 4, 7 és 14 napos DPSC sejttenyészeten is végeztünk ALP-aktivitásméréseket (4. kép), ezt HIDEX microplate readeren mértük. A 405 nm-en mért abszorbancia-növekedés arányos a szérum alkalikus foszfatáz aktivitásával. Az ALPaktivitás mértéke a Mg-zeolit és zeolit minták esetében is a magasabb $(0,605 \mathrm{mM})$ koncentrációnál mutatta a legmasabb értékeket. Az ALP enzim fontos szerepet tölt be a csontmátrix felépítésében, így gyakorlatilag a teljes csontformáció aktivitásáról ad jó, átfogó képet. A Mg-zeolit minták ALP-aktivitásának mérése során a 14. napon mind a kontroll mind a sima zeolit mintákkal összehasonlítva magas értéket mutat. Általánosan jellemző, hogy a Mg-zeolit értékek háromszorosai a zeolit értékeinek, ami jelzi, hogy a magnéziumnak fontos szerepe lehet.

\section{Megbeszélés}

A scaffold alkalmazásához két ígéretes új adalékanyag lehet a zeolit és a magnézium. A kísérletünk célja a zeolit és magnézium-zeolit koncentrációk hatásának vizsgálata volt tenyésztő médiumban fenntartott DPSC sejteken. A zeolitok 3D pórusos mikroszerkezete nagyszerü alapot szolgáltathat a csontsejtek egymással történő kapcsolódásának, proliferálódásának, differenciálódá- 


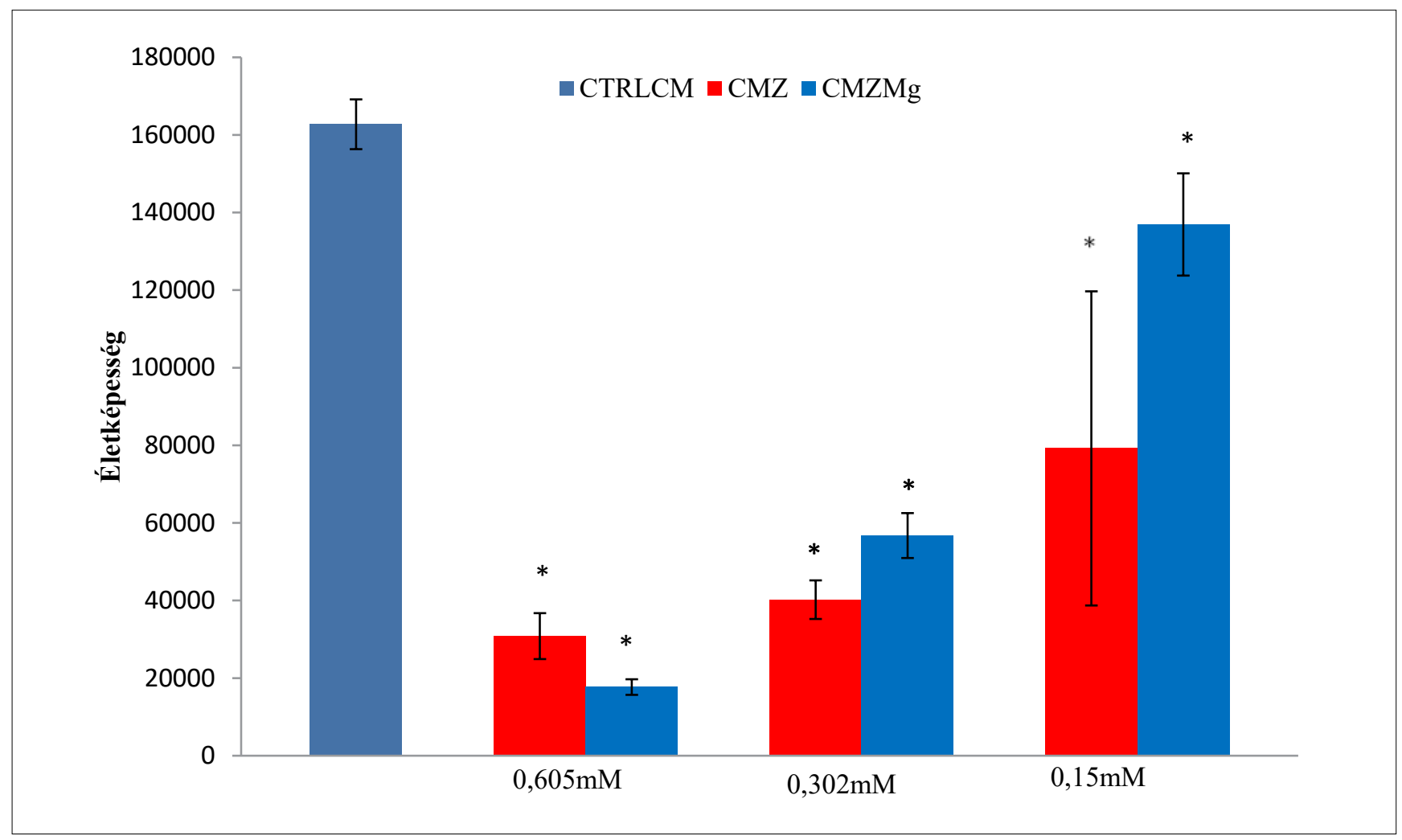

3. kép: Életképesség vizsgálat (Alamar Blue).

Különböző koncentrációjú Mg-zeolittal (ZMg) és zeolittal $(Z)(0,605,0,325,0,15 \mathrm{mM}$ cc) kezelt CM-ben (tenyésztő médium) tenyésztett DPSC sejtek és kontroll sejtek (CTRLCM) abszorbanciája a 14. napon.

ZMg és $Z$ egymással összehasonlítva. ${ }^{*} p<0,05$

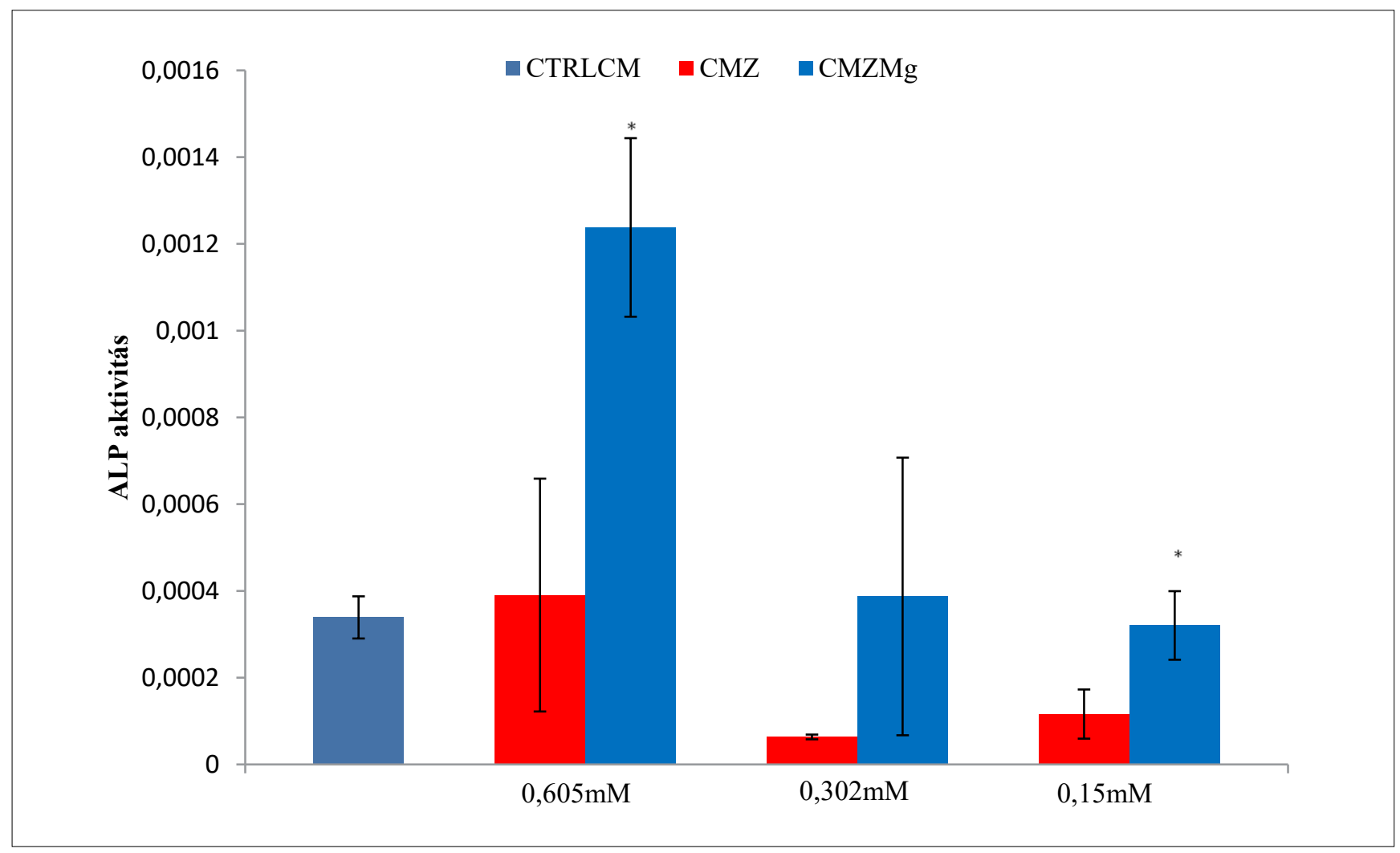

4. kép: ALP aktivitás mérése a különböző koncentrációjú Mg-zeolital $(Z M g)$ és zeolittal $(Z)(0,605,0,325,0,15 \mathrm{mM})$ tenyésztő médium (CM)-ban kezelt DPSC sejtek és kontroll sejtek (CTRLCM) abszorbanciája a 14. napon. 
sának majd végül szövetté formálódásának [1]. A mesterséges szövettenyésztést elősegítő tulajdonságai mellett az antimikrobiális és hatóanyag-kibocsátást szabályozó szerepe sem elhanyagolható [7]. In vitro kísérletek során zeolit és/vagy magnézium alkalmazásakor az alkalikus foszfatáz aktivitás értékek növekednek jól definiált koncentrációk esetében, ami korai markere a csontsejtek és a zeolit/magnézium tartalmú vizsgálati anyagok közötti kompatibilitásnak, a szövetképzési folyamat beindulásának $[3,8,10,21,23,27]$. Bár eltérések különböző sejttípusok esetében megfigyelhetők [23]. A zeolit tartalmú scaffoldok $\mathrm{pH}$-ja alacsonyabb, a magnéziumtartalmú scaffoldok esetében a zeolit csökkenti a felszabaduló hidrogén mennyiségét. A magnéziumtartalmú scaffoldoknál a korrózió és hidrogénfelszabadulás jelentős problémát okozhat $[4,15,17,18]$.

Az általunk mért életképességi vizsgálatok DPSC sejtek esetében is magasabb proliferációs értékeket mutatott a magnézium és zeolit együttes alkalmazásakor. Az Alamar Blue-val meghatározott életképesség-paraméterek a magnéziummal töltött zeolit esetében általában magasabb értékeket mutattak a kísérleti rendszerünkben. A Mg-zeolit- és zeolitkezelések az alacsonyabb koncentrációk esetében $(0,325,0,15 \mathrm{mM})$ magasabb életképességet és proliferációs értéket mutattak. Ez több irodalmi adattal összhangban lévő eredmény [23, 9, 7, 4]. A Mg-zeolittal kezelt DPSC sejtek abszorbancia-értékei magasabb értékeket mutattak a zeolitmintákkal összehasonlítva [4]. A zeolit alumínium- és szilíciumtartalma miatt mitogén hatással rendelkezik, és segíti az oszteogenezist. A bivalens kationok, mint a magnézium is, jelentős szerepet játszanak az oszteogenezis folyamatában és a „remodelling”-ben. Esszenciális szerepük van a ligand kötő fehérjék és sejtfelszíni fehérjék (integrin, vitronektin, fibronektin) interakciójában, stimulálják a sejtadhéziót, és a fokális adhéziók kialakulását is szabályozzák. A magasabb magnéziumkoncentráció egyes irodalmi adatok $[2,3,15,16,17,18,19]$ szerint szerepet játszhat a differenciálódási folyamatokban. A kísérleti eredmények alapján a magnéziummal ioncserélt zeolit hatása emelkedett ALP aktivitást mutatott a csak zeolitot tartalmazó mintákhoz képest. A Mg-zeolit-minták ALP aktivitása a vizsgálat során a 14. napon magasabb volt mind a kontroll, mind pedig a zeolitmintákkal összehasonlítva. A 14. nap a Mg-zeolit és a zeolit esetében is magasabb ALP intenzitás értéket ért el magasabb koncentráció esetében $(0,605 \mathrm{mM})$. Általánosan jellemző, hogy a Mg-zeolittal kezelt sejtek ALP aktivitás értékei háromszor magasabbak a csak zeolittal kezelt minták értékeinél, ami jelzi, hogy a magnéziumnak fontos szerepe lehet a csontosodási folyamatokban. Ez az eredmény korrelál más irodalmi adatokkal is $[4,23,24$, $25,26,27,28]$. Nagyon eltérőek az irodalmi eredmények különböző sejtvonalak esetében a hatásos magnéziumkoncentrációt illetően, ennek „titrálása” további kísérleteket igényel. Az eredmények alapján mindkét vizsgált lehetséges scaffold-komponens, a zeolit és a magnéziummal ioncserélt zeolit is ígéretes összetevője lehet a jövő mesterséges szövettenyésztést alkalmazó orvosi beavatkozásainak több területén is, a mi eredményeink alapján a magnéziummal ioncserélt zeolit tűnt a legígéretesebbnek.

Köszönetnyilvánítás: A tanulmány alapjául szolgáló kutatást az Innovációs és Technológiai Minisztérium által meghirdetett Felsőoktatási Intézményi Kiválósági Program NKFIH-1150-6/2019 számon támogatta, a Debreceni Egyetem Biotechnológia tématerületi programja keretében. A publikáció elkészítését a GINOP-2.3.2-152016-00011 és a GINOP-2.3.2-15-2016-00022 számú projekt támogatta. A projekt az Európai Unió támogatásával, az Európai Regionális Fejlesztési Alap társfinanszírozásával valósult meg. A mikroszkópos vizsgálatok elkészítését a GINOP-2.3.3-15-2016-00029 számú projekt támogatta. A projekt az Európai Unió támogatásával, az Európai Regionális Fejlesztési Alap társfinanszírozásával valósult meg.

\section{Irodalom}

1. Zarrintaj $P$, Mahmodi G, Manouchehri $S$, Mashhadzadeh $A$, Khodadad M, Servatan M, Mozafari M: Zeolite in tissue engineering: Opportunities and challenges. MedComm 2020; 1: 5-34. https://doi.org/10.1002/mco2.5

2. Kıм K-J, Сho S, Sang Cho Y, Yang S-J, Сho Y-S, Kıм KK: Magnesium ions enhance infiltration of osteoblasts in scaffolds via increasing cell motility. Journal of Materials Science: Materials in Medicine 2017; (6) 28. https://doi.org/10.1007/s10856-017-5908-5

3. Wu L, Feyerabend F, Schilling AF, Willumeit-Römer R, LUTHRINGER BJC: Effects of extracellular magnesium extract on the proliferation and differentiation of human osteoblasts and osteoclasts in coculture. Acta Biomaterialia 2015; 27: 294-304. https://doi.org/10.1016/j.actbio.2015.08.042

4. Saheban M, Bakhsheshi-Rad HR, Kasiri-Asgarani M, Hamzah E, ISMAIL M, AzIZ AF, DAYAGH E: Effect of zeolite on the corrosion behavior, biocompatibility and antibacterial activity of porous magnesium/zeolite composite scaffolds. Materials Technology 2018; (34): 5, 258-269. https://doi.org/10.1080/10667857.2018.1549803

5. Keeting PE, Oursler MJ, Wiegand KE, Bonde SK, Spelsberg TC, RIGGS BL: Zeolite an increases proliferation, differentiation, and transforming growth factor - production in normal adult human osteoblast-like cells in vitro. Journal of Bone and Mineral Research 2009; 7 (11): 1281-1289.

https://doi.org/10.1002/jbmr.5650071107

6. MölleR K, BeIn T: Mesoporosity - a new dimension for zeolites. Chemical Society Reviews 2013: (9): 42. https://doi.org/10.1039/c3cs35488a

7. Derakhshankhah $H$, Jafaris, Sarvari S, Barzegari E, Moakedi, Milad Ghorbani F, Shiri, Varnamkhasti B, Jaymand M, Izadi Z, TAYEBI Z: Biomedical Applications of Zeolitic Nanoparticles, with an Emphasis on Medical Interventions. International Journal of Nanomedicine 2020; 15: 363-386. https://doi.org/10.2147/IJN.S234573

8. Safari F, Houshmand B, NeJad AE: Application of Zeolite, a biomaterial agent, in Dental science: A rewiew article Regen Reconstr Restor 20183 (4) X-X doi: 10.22037/rrr.v3i4.24267

9. Alipour M, Aghazadeh M, Akbarzadeh A, Vafajoo Z, Aghazadeh Z, RaEISDASTEH HOKMABAD V: Towards osteogenic differentiation of human dental pulp stem cells on PCL-PEG-PCL/zeolite nanofibrous scaffolds. Artificial Cells, Nanomedicine, 
and Biotechnology 2019; 47 (1): 3431-3437. https://doi.org/10.1080/21691401.2019.1652627

10. Mohandesnezhad S, Alizadeh E, Pilehvar-Soltanahmadi Y, Davaran S, Goodarzi A, Khatamian M, Zarghami N, Samiel M, AghaZADEh M, AKBARZAdeh A: In vitro evaluation of novel Zeolitehydroxyapatite blended scaffold for dental tissue engineering. Biotechnology and Bioengineering 2020 https://doi.org/10.21203/rs.2.20452/v1

11. BEDI RS, ZANELLo LP, YAN Y: Osteoconductive and Osteoinductive Properties of Zeolite MFI Coatings on Titanium Alloys. Advanced Functional Materials 2009; 19 (24): 3856-3861. https://doi.org/10.1002/adfm.200901226

12. Purnomo, Setyarini PH, Sulistyaningsin D: Zeolite-based biomaterials for biomedical application: A review. AIP Conf. Proc. 2018; 1997:030013. https://doi.org/10.1063/1.5042933

13. Bedi RS, BeVIng DE, ZanelLo LP, Yan Y: Biocompatibility of corrosion-resistant zeolite coatings for titanium alloy biomedical implants. Acta Biomaterialia 2009; 5 (8), 3265-3271. https://doi.org/10.1016/j.actbio.2009.04.019

14. Bacakova L, Vandrovcova M, Kopova I, JiRKa I: Applications of zeolites in biotechnology and medicine - a review. Biomaterials Science 2018; 6 (5), 974-989. https://doi.org/10.1039/C8BM00028J

15. Gu X-N, LI S-S, LI, X-M, FAN Y-B: Magnesium based degradable biomaterials: A review. Frontiers of Materials Science 2014; 8 (3), 200-218. https://doi.org/10.1007/s11706-014-0253-9

16. ZHENG YF, Gu XN, WITTE F: Biodegradable metals. Materials Science and Engineering: R: Reports 2014; 77, 1-34. https://doi.org/10.1016/j.mser.2014.01.001

17. $\mathrm{XIN} Y, \mathrm{H} \cup \mathrm{T}, \mathrm{CH \cup} \mathrm{PK}$ : In vitro studies of biomedical magnesium alloys in a simulated physiological environment: A review. Acta Biomaterialia 2011; 7 (4), 1452-1459. https://doi.org/10.1016/j.actbio.2010.12.004

18. WITTE F: The history of biodegradable magnesium implants: A review. Acta Biomaterialia 2010; 6 (5), 1680-1692. https://doi.org/10.1016/j.actbio.2010.02.028

19. Zhao D, Witte F, Lu F, WANG J, Li J, QIN L: Current status on clinical applications of magnesium-based orthopaedic implants:
A review from clinical translational perspective. Biomaterials 2017; (112): 287-302. https://doi.org/10.1016/j.biomaterials.2016.10.017

20. LiU Y J, YANG ZY, TAN LL, LI H, ZHANG YZ: An animal experimental study of porous magnesium scaffold degradation and osteogenesis. Brazilian Journal of Medical and Biological Research 2014; 47 (8): 715-720. https://doi.org/10.1590/1414-431x20144009

21. Liu C, Fu X, Pan H, Wan P, Wang L, Tan L, Chu PK: Biodegradable $\mathrm{Mg}-\mathrm{Cu}$ alloys with enhanced osteogenesis, angiogenesis, and long-lasting antibacterial effects. Scientific Reports 2016; 6 (1) https://doi.org/10.1038/srep27374

22. De BaAiJ J, Hoenderop HF, Bindels RJM: Magnesium in Man: Implications for Health and Disease. Physiological Reviews 2015; 95 (1): 1-46. https://doi.org/10.1152/physrev.00012.2014

23. Burmester A, Luthringer B, Willumeit R, Feyerabend F: Comparison of the reaction of bone-derived cells to enhanced $\mathrm{MgCl} 2$-salt concentrations. Biomatter 2014; 4 (1). https://doi.org/10.4161/21592527.2014.967616

24. JANG WS, TAE JP: Magnesium Metabolism. Electrolyte Blood Press 2008 Dec; 6 (2): 86-95. https://doi.org/10.5049/EBP.2008.6.2.86

25. Kwon Y-D, LeE D-W, Hong S-O: Magnesium vs. machined surfaced titanium - osteoblast and osteoclast differentiation. The Journal of Advanced Prosthodontics 2014; 6 (3). https://doi.org/10.4047/jap.2014.6.3.157

26. Leidi M, Dellera F, Mariotti M, Maier JaM: High magnesium inhibits humanosteoblast differentiation in vitro. Magnes Res Mar 2011; 24 (1): 1-6. https://doi.org/10.1684/mrh.2011.0271

27. Mammoli F, Castiglioni S, Parenti S, Cappadone C, Farruggia G, IOTTI S, FrassinetI C: Magnesium is a Key Regulator of the Balance between Osteoclast and Osteoblast Differentiation in the Presence of Vitamin D3. International Journal of Molecular Sciences 2019; 20 (2). https://doi.org/10.3390/ijms20020385

\section{Szilágyi I, Czibulya Zs, Csík A, Braun M, Hegedüs Cs}

\section{Zeolite and deionised zeolite with magnesium in vitro comparative study}

Examination of the zeolite and magnesium-exchanged zeolite system on human stem cells culture, different viability and ALP activity values at different concentrations provide information on the factors influencing ossification and bone "turnover". The aim of our present work was to investigate the effect of zeolite and magnesium ion-exchanged zeolite concentrations $(0.605 \mathrm{mM}, 0.325 \mathrm{mM}, 0.15 \mathrm{mM} \mathrm{Mg}$-zeolite and zeolite) in an in vitro experimental system on culture medium from wisdom tooth cells (DPSC - dental pulp stem cells) at different sampling times (1, 4, 7 and 14 days).

Based on our measurements of viability and alkaline phosphatase activity, both components studied, zeolite and magnesium-ion-exchanged zeolite could be promising components of future medical interventions using artificial tissue culture in several areas. Our experiments showed that Mg-zeolite was more effective.

Keywords: magnesium, zeolite, DPSC, scaffold 